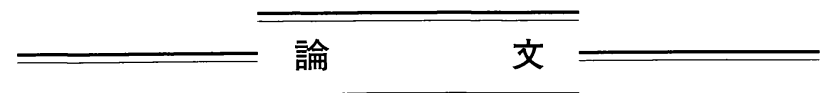

農業気象(J.Agric. Meteorol.) 51 (2): 123-130, 1995

\title{
ビデオカメラを用いたホウレンソウ葉 の運動の連続計測
}

\author{
星岳彦* 瀧口 武** \\ $\left(\begin{array}{c}* \text { 東海大学開発工学部 } \\ * *\end{array}\right.$
}

\section{Continuous Measurement of Movement in Spinach Leaves Using Video Cameras}

\author{
Takehiko HosHi* and Takeshi TAKIGUCHI** \\ ( ${ }^{*}$ Department of Biological Science and Technology, Tokai University, \\ 317, Nishino, Numazu, Shizuoka, 410-03 Japan \\ **The Fruit Vegetable Division, Kanagawa Horticultural Experiment Station, \\ 1217, Ninomiya, Naka-Gun, Kanagawa, 259-01 Japan
}

\begin{abstract}
Leaf movement together with growth of vegetables was continuously measured by two video cameras and a three-dimensional image processing system. In the experiment, the leaf movement of spinach (Spinacia oleracea L. cv. "Lead") from 10 to 24 days after seeding in two different photosynthetic photon flux densities (PPFD) was observed.

A diurnal movement in spinach leaves was observed of both high and low PPFD. Spinach folded all the leaves in the dark period and spread the leaves in the light period. The amplitude of the diurnal movement showed a tendency to increase with high PPFD and increasing growth of the leaf blade.' An irregular falling-rising movement due to infirm growth and a periodical swing movement with 3 hours on several leaves was also observed at low PPFD.

It is considered that the physiological condition of spinach affects the kind and amplitude of the movement. The experimental results indicate that the measurement of the movement is a possible method to monitor vegetable growth in environmental control systems.
\end{abstract}

Key words: Computer measurement, Image processing, Leaf movement, Spinach.

キーワード：画像処理, コンピュータ計測, 葉の運動, ホウレンソウ

\section{1.はじめに}

環境制御システムの性能を高めるためには，植物の生 理状態を制御にフィードバックする必要がある。これま で, 植物の生理状態を得る目的で各種生体情報の計測が 試みられて，環境制御へ応用されてきた。一例をあげる と, 炭酸ガスの吸収量による純光合成速度の計測之制御 (Lake, 1966 ; Takakura et al., 1974), 生体電位の計

1993 年 4 月 2 日 全国大会汇て発表 1994 年 9 月 27 日 受付, 1995 年 3 月 15 日 受理
測(関山ら, 1982；三輪ら, 1987；内田ら, 1990)，クロ ロフィル蛍光の計測 (Methy and Salager, 1989) 等が 行われた。

植物体の形, 色彩, テクスチャの状態やそれらの恋化 などは, 植物の生理状態を栽培者が知るための指標とし て古くから活用されている. そてで, 形態や色彩の変化 をセンサで自動計測する研究す行われてきた。. 茎径, 果 径, 花蕾の大きさの連続的計測法として, ストレーンゲ ージを使う方法 (二ノ方・宮里, 1959), 差動卜ランスを 使う方法 (Kadoya, 1973 ; 鴨田・内藤, 1975), ポテン 
ショメータを使う方法 (Haung, 1974), 静電容量を計測 する方法 (岩尾・高野, 1989)等が用いられた。また, 色 変化の計測については, 中西ら (1989), 鳥居ら (1990) の研究が行われた。

さらに, コンピュータ技術の進歩に伴い, 撮影された 植物画像を解析して, 植物の成長に関する情報を得よう とする研究が行われた。Matsui and Eguchi (1976)は, キュウリの画像処理によって画像面積から植物成長量の 定量化を試み, 柴田ら (1993) は, レタスの投影面積か ら植物成長量を得ようと試みた。また, 江口ら (1991) は, レタスの個葉に印を付け, その位置の変化を画像解 析するてとによって, 気温によって葉が非等方的に成長 するてとを明らかにした。

植物の各器官が成長・発達に伴って運動することはよ く知られている。Darwin(1882)は, 300 種以上の植物 の葉, 茎, まきひげなどの運動について観察した。顕著 な就眠運動, 捕食運動などを行う, マメ科, カタバミ科, モウセンゴケ科の植物については, その運動の特性やメ カニズムが詳細に研究されている(柴岡, 1981)。近年に なって, 蔬菜類の運動についても, 微速度撮影からサラ ダナ葉の運動が成長と関連しているようであるという指 摘(中島, 1993)がある。著者らむ，植物工場においてサ ラダナ, ホウレンソウ, トマト等の葉が運動することを 観察している。蔬菜類葉の運動速度は $50 \mu \mathrm{m} ・ \mathrm{~s}^{-1}$ を越え るむのは少ないので, 肉眼の詳細な観察は困難を極める。 乙の運動の詳細かつ連続的な計測は，乙れまでほとんど 報告されていない。乙の計測は, 画像計測とコンピュー 夕を利用した画像解析によって容易に実現できる。

本研究では, ビデオカメラを用いて, 播種後約 10 日 目の苗からほぼ収穫可能になる 24 日目までの期間, 異 なる光環境条件下で栽培されているホウレンソウを連続 的に撮影した。そして, 撮影された画像からホウレンソ ウ葉の運動を 3 次元的に解析した。

\section{2. 材料および方法}

\section{1 立体画像計測}

物体形状の立体計測装置として磁気式 3 次元デジタイ ザがある。植物の立体形状の計測にあ利用されている(本 條ほか, 1993)。しかし, 温室骨材などの金属物体によ り計測誤差を生じ, 柔軟な植物の特定の部位を正確に卜 レースすることが難しく, 人手による実時間計測が必要 なので長期間連続計測に不適で, 今回の目的には適当で ない。

一方, 画像計測による方法として, 視差を用いて計測 点の位置を計算する立体写真法がある（Minagawa， 1994 )。自動撮影して, 後でまとめて位置情報を計算で
きるので長時間連続計測が可能であるが, 撮影した画像 の前後方向の計測精度を高めることが難しい。また, 一 方向から対象物を撮影するので, 重なり合って立体的に 展開するホウレンソウ葉序の場合には, 計測点が隠れて 全く計測できない部分が多くなってしまう。そてで, 植 物体の上方拉よび側方に，それぞれ 1 台のビデオカメラ を設置して画像を収録し, 直交 2 方向からの透視画法に よる立体画像計測を行った。

撮影するホウレンソウの周囲に鉄製 L アングルで架台 を設置し， $8 \mathrm{~mm}$ カラービデオカメラ（Sony 製 CCD TR 75, 41 万画素撮像素子内蔵)を 2 台設置した。カメラ には,ズームレンズ(焦点距離 7.8 から $62.4 \mathrm{~mm}$ ) が装着 された。錘付きの道系, 水準器を用いて, 光軸が直交す るようにカメラをねじで架台に固定し, 光軸交点を定め た。さらに, 計測した pixel 数を実際の長さに換算する ために，表面に方眼紙を貼付した基準立方体を用意した。 水準器とカメラの画像を使って, 基準立方体のカメラに 向かう面が, それぞれのカメラの光軸と直交するように 設置した。

カメラは, 録画待機状態にしておき, カメラの遠隔操 作端子から録画開始・中断の接点信号線を取り出し, 半 導体タイマーに接続して自動微速度撮影を行った。暗期 の収録光源として，40 W の白熱電球をホウレンソウの 斜め上方に設置した。撮影のプロセスは, まず白熱電球 を点灯し, カメラの露出と焦点調節機構を安定させるた めに 1.5 秒間待つ。次に, 0.5 秒間録画開始信号を出力し, 録画を開始し, 1.5 秒間待つ。続いて, 0.5 秒間録画中断 信号を出力し, 録画を停止する。その直後, 白熱電球を 消灯し, 1 回の撮影サイクルが完了する。乙の撮影方法 によって, 3 分毎に約 2 秒間の画像を $8 \mathrm{~mm}$ ビデオカセ ットテープに連続収録した。

収録した画像は，ビデオデジタイザ(Raster Ops 製 $24 \mathrm{STV}$ ) を使い, 画像取り込みソフトウェア (Raster Ops 製 Media Grabber)によって，608×456 pixelsで 色情報 8 bits のカラー画像にディジタイズし, 3.5 イン チ光磁気ディスクに収録した。そして，上方抒よび側方 の二方向から同時刻にホウレンソウを撮影したふたつの 画像を使って, 計測点の 2 次元座標を pixel 単位でそれ ぞれ計測した。この 2 組の 2 次元座標データを突き合わ せ, ホウレンソウの茎頂を原点とする $\mathrm{cm}$ 単位の 3 次元 座標に変換するソフトウェア(Pict Meas)を開発した。 Pict Measを用いて, 子葉を含む全ての葉の先端および 葉柄との接続点を 3 次元座標データに变換した。

\subsection{Pict Meas のアルゴリズム}

Pict Measは, 2 台のカメラを直交する方向に設置し て撮影した画像データの計測点の 2 次元座標データ, お 


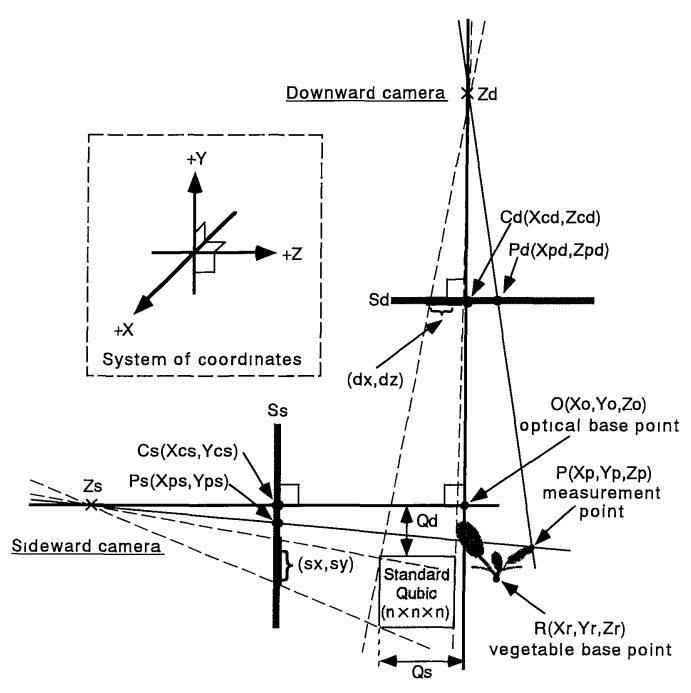

Fig. 1. Symbolic system for measurement of the three-dimensional coordinates on spinach.

よび，基準立方体の画像上での大きさから，計測点の 3 次元座標を計算する。アルゴリズム説明のために, Fig. 1 の通り記号を定める。

添字の d は上方のカメラを, $\mathrm{s}$ は側方のカメラを表す。 $\mathrm{Zd}$ およびZs はカメラの光学上の焦点, Sd および Ss は, 撮影された映像が写るスクリーンを示す。また，点Oは 2 台のカメラ光軸の交点, 点 $\mathrm{R}$ は植物体の基準点, 点 $\mathrm{P}$ は計測点を表す。点 $\mathrm{Cd}, \mathrm{Pd}, \mathrm{Cs}, \mathrm{Ps}$ は, 点Oおよび点 $\mathrm{P}$ をスクリーン上で見た点で, pixel を単位にした 2 次 元座標値である。

ここで $\mathrm{a} \bullet \mathrm{b}$ を点 $\mathrm{ab}$ 間の距離と定義し, $d d, d s, f d$, fs を定める。

$$
\left.\begin{array}{l}
d d=\overline{\mathrm{Zd} \cdot \mathrm{O}} \\
d s=\overline{\mathrm{Zs} \cdot \mathrm{O}} \\
f d=\overline{\mathrm{Zd} \cdot \mathrm{Cd}} \\
f s=\overline{\mathrm{Zs} \cdot \mathrm{Cs}}
\end{array}\right\}
$$

まず， $d d$ と $d s$ を実測する。さらに， $n \mathrm{~cm}$ 角の基準立 方体の占める綐横の pixel 数を計測し, 上方スクリーン の分を $d x, d z$ とし, 側方スクリーンの分を $s x, s y$ とす る。すると, 1 pixel の縦横比である $k d, k s$ が求められ る。

$$
\left.\begin{array}{l}
k d=\frac{d x}{d z} \\
k s=\frac{s x}{s y}
\end{array}\right\}
$$

また，それぞれのカメラに向く基準立方体の面が，力 メラ光軸方向に点Oからずれている長さを $Q d, Q s$ とし, それを実測する。乙の場合の符号は, 点Oからカメラに
向かう方向をマイナスとする。

すると, 未知の值である $f d, f s$ が次式で求められる。

$$
\left.\begin{array}{l}
f d=\frac{1}{n}(d d+Q d) d x \\
f s=\frac{1}{n}(d s+Q s) s x
\end{array}\right\}
$$

次に, 点 $\mathrm{Cd}, \mathrm{Pd}, \mathrm{Cs}, \mathrm{Ps}$ pixel単位で計測し, 以 下の値を計算する。

$$
\left.\begin{array}{l}
X d l=X c d-X p d \\
Z d l=Z p d-Z c d \\
X s l=X p s-X c s \\
Y s l=Y c s-Y p s
\end{array}\right\}
$$

すると, 点 $\mathrm{O}$ 原点とした点 $\mathrm{P}$ の座標 $\left(X^{\prime} p, Y^{\prime} p, Z^{\prime} p\right)$

は，(5)式で求めることができる。

$$
\left.\begin{array}{rl}
X^{\prime} p & =\frac{X d l(d d \cdot f s-Y s l \cdot d s \cdot k s)}{f d \cdot f s+Y s l \cdot Z d l \cdot k d \cdot k s} \\
& =\frac{X s l(d s \cdot f d+Z d l \cdot d d \cdot k d)}{f d \cdot f s+Y s l \cdot Z d l \cdot k d \cdot k s} \\
Y^{\prime} p & =\frac{Y s l(d s \cdot f d+Z d l \cdot d d \cdot k d) k s}{f d \cdot f s+Y s l \cdot Z d l \cdot k d \cdot k s} \\
Z^{\prime} p & =\frac{Z d l(d d \cdot f s-Y s l \cdot d s \cdot k s) k d}{f d \cdot f s+Y s l \cdot Z d l \cdot k d \bullet k s}
\end{array}\right\}
$$

また, $X^{\prime} p$ については 2 通りの算出式が使用できるの で, 計測の検証に使用できる。

同様にして, 点 $\mathrm{O}$ を原点とした点 $\mathrm{R}$ の座標を求める。 点 $\mathrm{P}$ と点 $\mathrm{R}$ の座標から, 点 $\mathrm{R}$ を原点にした点 $\mathrm{P}$ の座標を 最終的に求められる。

\section{3 ホウレンソウ栽培}

ホウレンソウ (Spinacia oleracea L.cv. “Lead") は密閉ガラス室内で湛液式養液栽培を行った。大塚 $\mathrm{A}$ 処 方に大塚 5 号肥料を $30 \mathrm{~g} \cdot \mathrm{m}^{-3}$ 添加した培養液を用い， 電気電導度を $0.24 \pm 0.02 \mathrm{~S} \cdot \mathrm{m}^{-1}$ に，水素イオン濃度を $6.0 \pm 0.5$ 亿制御した。培養液循環は 0.5 時間周期で 0.25 時間行った。気温は明期 $25^{\circ} \mathrm{C}$, 暗期 $20^{\circ} \mathrm{C}$ 亿比例制御 し，相対湿度は $60 \%$ 以上に加湿制御し， $\mathrm{CO}_{2}$ 濃度は明 期のみ $750 \mathrm{ppm}$ 以上に制御した。明期は 6 時から 18 時 までの 12 時間, 暗期は 18 時加.ら翌 6 時までの 12 時間 とし, 暗期には光線透過率 $30 \%$ の遮光カーテンを展張し た。

ホウレンソウ葉の展開状態は, 明期と暗期で異なるて とを観察している。そてで, 葉の運動に光が関連してい ると考元, 強光区之弱光区の光条件を用意し, 対照実験 を行った。強光区は, 明期屋外の水平面光合成有効光量 子束密度 (Photosynthetic Photon Flux Density, 以下 PPFD と略す)が $300 \mu \mathrm{mol} \cdot \mathrm{m}^{-2} \cdot \mathrm{s}^{-1}$ を下回ったときに, $165 \mathrm{~W} \cdot \mathrm{m}^{-2}$ の投入電力でメタルハライドランプによる補 
光を行った。これは, ランプ直下の栽培ベッド面の P P FD で約 $200 \mu \mathrm{mol} \cdot \mathrm{m}^{-2} \cdot \mathrm{s}^{-1}$ の補光になった。弱光区は，屋 外 PPFDが $300 \mu \mathrm{mol} \cdot \mathrm{m}^{-2} \cdot \mathrm{s}^{-1}$ を上回ったときに，光 線透過率 $30 \%$ の遮光カーテンを展張した。

\section{3. 結果}

\section{1 立体画像計測の精度}

ホウレンソウ計測時の $d d$ は $113.0 \mathrm{~cm}, d s$ は $71.2 \mathrm{~cm}$ になった。そして， $n=3.0 \mathrm{~cm}$ の基準立方体を， $Q d=$ $-1.5 \mathrm{~cm}, Q s=3.2 \mathrm{~cm}$ の位置に設置した。乙の計測条件 での光軸の交点 $O$ を中心とする直径 $20.0 \mathrm{~cm}$ の球体空間 内の計測分解能は，側方から計測したX座標が 0.40 から $0.53 \mathrm{~mm} \cdot \mathrm{pixel}^{-1}$, Y座標が 0.38 から $0.50 \mathrm{~mm} \cdot \mathrm{pixel}^{-1}$ になり，上方から計測したX座標が 0.77 から $0.92 \mathrm{~mm}$ ・ pixel $^{-1} ， Z$ 座標が 0.77 から $0.92 \mathrm{~mm} \cdot$ pixel $^{-1}$ 亿なった。

光学系およびビデオ信号処理系の計測精度を調べるた めに，ホウレンソウを計測する場合とほぼ同様の画角で, 一辺が $20.0 \mathrm{~cm}$ の正方形を $100.0 \mathrm{~cm}$ の距離から撮影して 録画した。乙の時の全画像面積に対する正方形の面積は $28.5 \%$ になった。その再生信号を計測方法と同様の方法 でディジタイズした。こうして得られた画像上の正方形 には, 極めて弱い歪曲(系巻収差)か観察されたが, 歪み の大きさは最あ顕著なところで 1 pixel であった。した がって, 前段落の計測条件であれば, 光学系およびビデ オ信号処理系だけでは最大 $0.92 \mathrm{~mm}$ の誤差で計測が可能 であると推定できた。

また，計算アルゴリズムの代数的処理の正しさは，数 式処理ソフトウェア(Mathematica)によって検証した。

続いて，ホウレンソウを用いて予備計測を行った。ホ ウレンソウの各部位を 10 箇所今回の方法で計測し，定 規を使って手計測した值との比較を行った。上記のホウ レンソウの計測条件では, $\pm 5.0 \mathrm{~mm}$ 以内の誤差で各座標 を計測できることが確められた。

\section{2 光環境に関わる運動}

強光区の播種後 22 日目のホウレンソウを午前 0 時か ら 12 時までの 12 時間, 4 時間毎に側方から収録した画 像を合成したものを Fig. 2 亿示した。暗期に直立して閉 じていた葉が，明期になるととむに，葉を展開する概日 性の就眠運動が示された。就眠運動は, 強光区之弱光区 の両方のホウレンソウで認められた。

ホウレンソウの本葉第 1 葉と第 2 葉の葉身先端の 1 時 間毎の位置変化を, 強光区は播種後 11 日目から 23 日目 までの軌跡として, 弱光区は播種後 10 日目から 24 日目 までの軌跡として，それぞれ，立体グラフにしたものを Fig. 3 亿示した。ホウレンソウの葉が就眠運動を行いな がら成長に伴って伸長していくことが，グラフのぎざぎ ざした軌跡によって示された。また, 強光区よりあ弱光 区の軌跡の方が，茎頂から上方向により大きな弧を描い ており，葉が立ち気味に伸長していることが示された。 また, 弱光区では, Fig. 3 で “irregular movement” と示した振幅の大きな非定常な軌跡が現れた。

さらに, 光環境条件との関連を観察するために, 本葉 第 1 葉と垂線との成す角度を 1 時間毎什計算し，それを PPFDの経時変化と共に示したあのをFig. 4 亿示した。

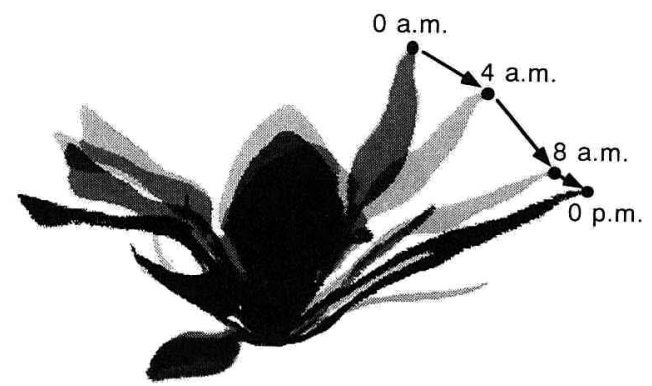

Fig. 2. Leaf movement of spinach at high PPFD (average $350 \mu \mathrm{mol} \cdot \mathrm{m}^{-2} \cdot \mathrm{s}^{-1}$ ) 22 days after seeding.

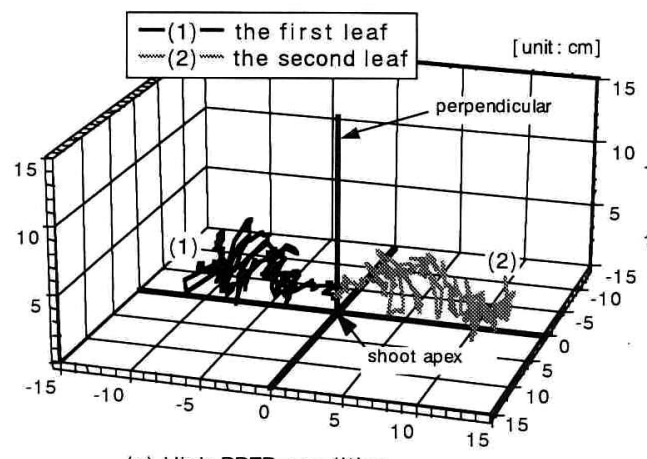

(a) High PPFD condition (from 11 to 23 days old spinach after seeding)

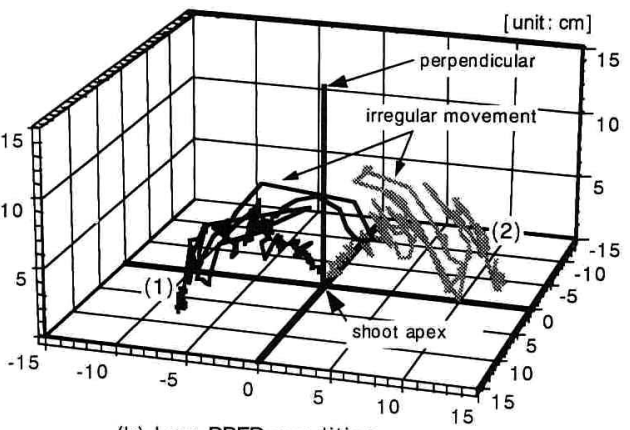

(b) Low PPFD condition

(from 10 to 24 days old spinach after seeding)

Fig. 3. Locus of the leaf tops with growth and movement at different PPFD. 


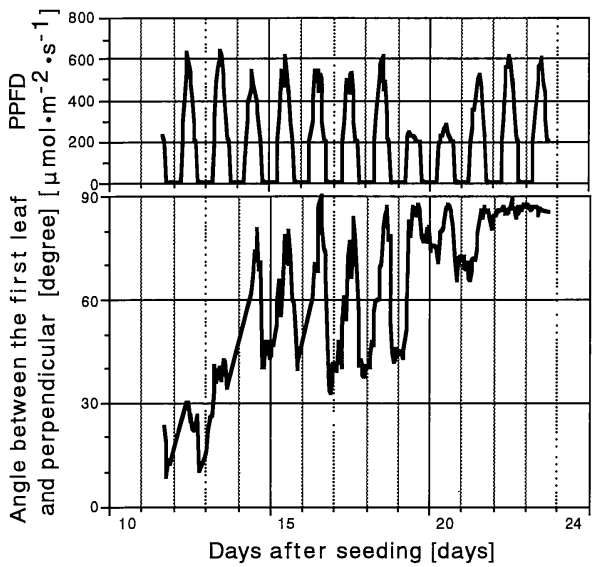

(a) High PPFD condition

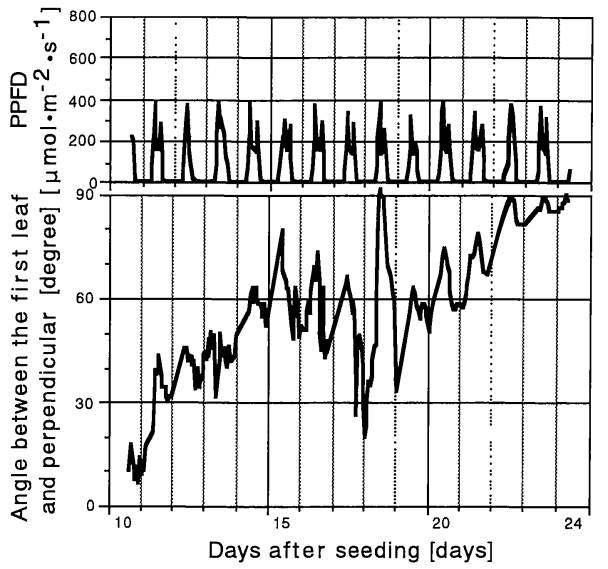

(b) Low PPFD condition

Fig. 4. Time-courses of PPFD and the first leaf angle at different PPFD.

どちらの区においても，葉はほぼ垂直の状態から，伸長 するにつれて水平に展開した。全計測期間の本葉第 1 葉 之垂線との成す平均角度は, 強光区が 63.7 度, 弱光区が 56.9 度で, この值からあ弱光区の葉が立ち気味であるこ とが示された。

Fig. 4 の角度变化からあ, Fig. 2 でも指摘したホウレ ンソウの成長に伴う就眠運動が示された。そして, PPFD との対応から，明期に葉を水平方向に展開し，暗期に葉 を垂直方向に閉塞する運動であるととがより明確に示さ れた。また, 強光区の成長中期に就眠運動が強く起てっ ているととが, 角度変化の振幅の大きさから読み取れた。 一方, 弱光区では, 強光区に比較して就眠運動の振幅は 全計測期間を通じて小さいが，播種後 18 日目に Fig. 3 であ指摘した非定常な運動が記録された。

\section{3 自律的な振動運動}

観察する時間スケールを 20 分毎に拡大すると, 弱光 区の特定の葉で別の運動が認められた。播種後 23 日目 のホウレンソウを真上から見下ろした場合の, 本葉第 5 葉の先端の軌跡を表したものをFig. 5 亿示した。Fig. 5 では，軌跡を見やすくするためにZ軸を 3 倍に拡大して， 葉身先端が運動した軌跡を示した。X軸方向の変動は, 葉を左右に振る運動である。また, 葉が水平に展開して いる程, 真上から見たホウレンソウの見かけの葉の長さ が長くなるのでZ軸の值は大きくなった。軌跡は，Darwin （1882）が旋回運動と呼ぶ運動パターンに酷似していた。

Fig. 5 の軌跡全てをX軸とZ軸成分に分解して, PPFD の経時変化と共に Fig. 6 亿示した。Fig. 6 のZ軸方向の 運動は, Fig. 2 で示した覚醒期の就眠運動である。X軸 方向には, 約 3 時間の周期をむって葉を左右に振動させ る自律的な振動運動が認められた。その最大速度は 22

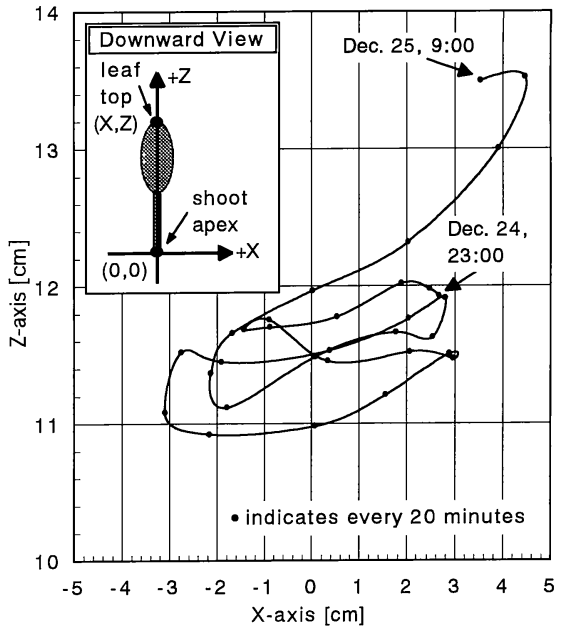

Fig. 5. Locus of the fifth leaf top from downward view in low PPFD at 23 days after seeding.

$\mu \mathrm{m} \cdot \mathrm{s}^{-1}$ に達した。

\section{4. 考察}

\section{1 立体画像計測の性能および問題点}

予備計測から, 今回実施したホウレンソウの計測条件 では, 最低 $0.92 \mathrm{~mm} ・ \mathrm{pixel}^{-1}$ の分解能でX, Y, Z座標を 計測可能であった。とのととは, $1.4 \mathrm{~mm}$ 以上の長さのよ゙ のような傾きの物体であ識別可能なととを意味する。ま た, 手計測値との比較で屯, $\pm 5.0 \mathrm{~mm}$ 以内の誤差での計 測が可能であった。計測精度の実測結果から, 光学系お よびビデオ信号処理系の誤差の割合は小さく, むしろ, 少々の接触で位置を変えてしまうホウレンソウ葉を定規 で手計測したときの誤差, 画像着目点のマウスを使った 


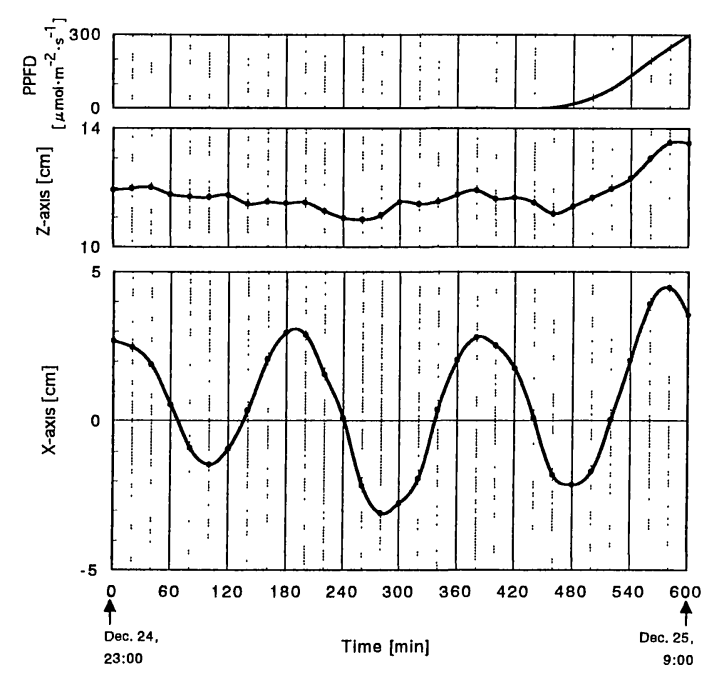

Fig. 6. Time-courses of PPFD, Z-axis vector movement, and $\mathrm{X}$-axis vector movement in Fig. 5 locus.

位置指定のずれによる誤差等の割合が大きかったと考え る。

今回試作した計測システムでは，いくつか不都合が生 じている。まず，カメラを長期間録画待機状態にしてい る。乙のため, 録画へッドの污染と磨耗が激しく, 撮影 期間中は 1 日に最低 1 回の録画ヘッドの清掃が必要であ った。コマ撮り機能のあるビデオカメラを用意するか, 直接デジタイズしてコンピュータの画像データファイル として蓄積する方が望ましい。

また，暗期の撮影が必要であるので，撮影時だけ 4 秒 間程度白熱灯を点灯した。長日性植物であるホウレンソ ウでは，乙のために暗期の中断が起とり，成長後期に花 芽分化, 抽苔してしまった。ホウレンソウに対する暗期 の非侵襲計測を行うためには, 暗視カメラ等の使用が必 要である。

さらに, Pict Measによる座標計算のため, コンピュ ータディスプレイに表示された画像の葉身先端等の計測 点を, マウスを使って人手で位置指定した。ヒトの運動 解析等で一般的に実施されているての方法は, 計測の労 力が極めて大きく, 自動化を妨げる最大の問題である。 従って, 本立体計測法を環境制御システム等へ応用する 場合には, 画像から計測点抽出の自動化を図る必要があ る。さらに, 別な葉の影に隠れたために葉の計測が不能 になった場合ああったので, さらに撮影点を増やしたり, 撮影位置を工夫したりすることも必要だと考える。

\section{2 枼の運動に関わる要因}

ホウレンソウ葉は概日的な就眠運動を行いながら成長 する。しかしながら, Fig. 2 およびFig.4亿す示されて
いる通り, 明期の開始 (午前 6 時) によるPPFDの増加 と共に葉が開き始めるのではなく, 暗期の終了数時間前 には，すでに葉の展開を開始している。光と関連する植 物の運動は, 屈光性現象之傾光性現象に分類できる。就 眠運動は傾光性現象であり, 単純な光反応ではないが, 基本的には光による反応として説明されている(佐々木, 1984 )。今回得られた結果む, ホウレンソウの就眠運動 が単純な光反応によるあのだけではなく, 概日性リズム 等の複数の生理的メカニズムの複合によって制御されて いることを示唆していると考える。いくつかの植物で は概日性リズムは青色光で制御可能であるという報告 (Satter et al., 1981) ああり, 赤色光之遠赤色光で制御 されるフィトクロムによる光反応との区別を行うために， 光質を制御した実験系を組む乙とがホウレンソウの就眠 運動メカニズムを解明するうえで必要であると考える。 また, 概日性りズムがリミットサイクルであるという観 点 (中島, 1991) からは, 光照射のタイミングを微妙に 調節するととによって, 特異点の存在を調べる実験屯必 要である。

Fig. 3 およびFig. 4 で認められた非定常な運動の原因 を調べるために録画したビデオテープを再生して詳細に 観察した。すると, 弱光区のホウレンソウは, 播種後 11 日目之 18 日目に地上部が倒伏し，その後起き上がりを 行っていた。乙の倒伏・復元が大きな角度の変動を示す 原因であることが判明した。乙れは, 光環境条件によっ て上胚軸の強度が不足し, 地上部が倒伏・復元を繰り返 す不安定な状態が生じたためであると推察できた。その 中で, 本葉第 1 葉が特に大きく傾いた播種後 18 日目の 倒伏がFig. 4 で特に大きく示された。乙のととから, 木 ウレンソウの不規則な運動を検出するてとによって, 光 環境条件による徒長という生理状態を検出する指標とし て使用できると考える。

就眠運動は, 葉の成長ステージによってその大きさが 異なるようである。そてで, 計測した座標データから, ホウレンソウの本葉第 1 葉の葉身長と葉柄長を 1 時間毎 に計算し,ささに, 葉と垂線が成す角度の毎日の変動値 との関係を Fig. 7 亿示した。弱光区の倒伏による大きな 角度の変動を除くと, 葉身の伸長に伴って葉の運動が盛 んになり, 葉身の伸長が停止すると共に葉の運動む小さ くなって行った。乙れは, 葉の成長等の生理現象之葉の 運動とに関連があるととを示すひとつの根拠であると考 える。

弱光区で観察された自律的な振動運動は, 弱光区の播 種後約 20 日目以降の数枚の葉で認められた, 特に顕著 に運動していたのが本葉第 5 葉であった。強光区では, 自律的な振動運動と明確汇認められるものは観察できな 


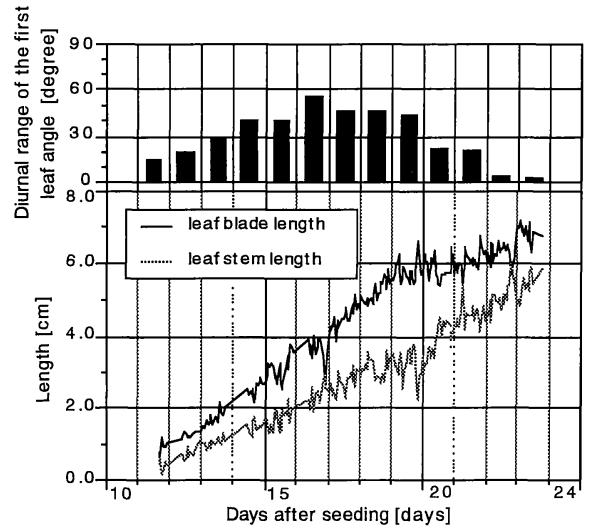

(a) High PPFD condition

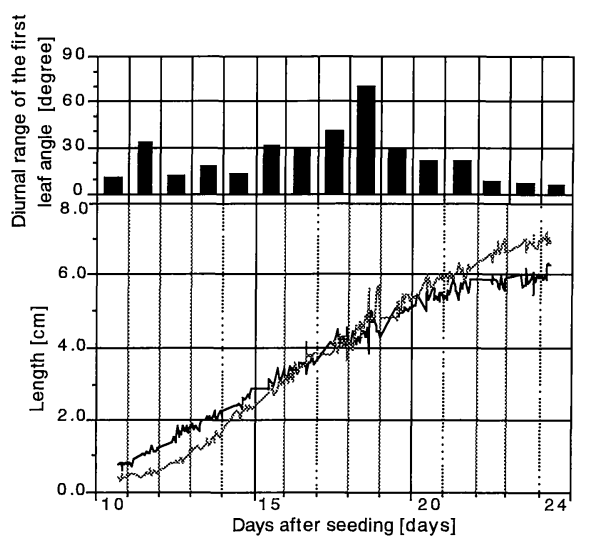

(b) Low PPFD condition

Fig. 7. Time-courses of the diurnal changes of the first leaf angle and the length of the first leaf blade and stem at different PPFD.

かった。自律的振動運動が発生する条件は, 今回の計測 結果からは明確にならなかった。また，その発生原因に ついてあ葉温振動之同じような何らかのフィードバック によるハンチング現象が生じているのか, 成長に非等方 性が生じるためなのか, 植物のまきひげ等が巻き付く対 象を探すために行う運動のようなすのなのか, 今後の検 討が必要である。

\section{3 画像計測による成育状況の把握}

葉の運動以外にも，画像情報を解析することによって， ホウレンソウ各器官の成長特性が計測可能であった。

たとえば, Fig. 7 の葉身長, 葉柄長を示すグラフの傾 きの変化から, 強光区では播種後 19 日目で本葉第 1 葉 の伸長がほぼ終了し, 弱光区では 21 日目で終了し, 両 区に約 2 日の開きがあることが読み取れる。また，葉柄 の伸長はその後も続くこと, 弱光区では葉身長よりも葉 柄長の方が長くなるとと等, 器官・光環境の違いによる 成長特性の違いが実測できている。

\section{5. 結 論}

ビデオカメラによる直交 2 方向からの透視画法による ホウレンソウ葉運動の画像計測を行い, 以下の結果を得 た。

(1) $\pm 5.0 \mathrm{~mm}$ 以内の誤差で, 播種後 10 日目から 24 日 目のホウレンソウ各器官の連続非破壊立体計測が実 現できた。

（2）ホウレンソウ葉は成長に伴って就眠運動を行って いる。乙の運動は, 光刺激によって引き起てされる だけでなく，概日性リズム，葉の成育ステージ等の 影響が考えられた。

（3）播種後約 20 日目以降の弱光区ホウレンソウの葉
で, 3 時間周期の自律的な振動運動が観察された。 （4）葉の運動計測以外にあ, ホウレンソウの徒長や各 器官の成長特性が計測可能であった。

謝 辞

本研究は, 平成 4 年度文部省科学研究費補助金奨励研 究 (A) 04760178 「植物の形態变化に基づいた植物生体 情報の非破壊測定法の基礎的検討」による援助を受けた。 また, 東海大学の林真紀夫氏には, 本稿の執筆にあたり 数多くの有益なご指摘をいただいた。記して謝意を表す る。

\section{引用文献}

Darwin, C., 1882: The power of movement in plants. John Murray, London (渡辺 仁訳, 植物 の運動力, 森北出版, 東京, pp. 499).

江口壽彦・筑紫二郎・江口弘美, 1991 ：レタス個葉にお ける非等方的生長の画像解析一葉の形状に対する温度 効果について一. 生物環境調節, 29 (3), 141-145.

Haung, B. K., 1974: Electric circumference meter for continuous monitoring of plant and fruit growth. Trans. of the ASAE, 493-495.

本條 均・庄野浩資・高辻正基, 1993：植物形状の測定 之可視化. 植物工場学会誌, 4 (2), 151-156.

岩尾憲三・高野泰吉, 1989 ：植物生体情報の計測手法の 開発とその応用に関する研究 (第 3 報) 植物の成長・肥 大の非破壊連続測定法の開発. 生物環境調節, 27 (2), $57-60$.

Kadoya, K., 1973: Studies on the translocation of photosynthesis in fruit growth and some environmental conditions. J. Jpn. Soc. Hort. Sci., 42, 215-220.

鴨田福也・内藤文男, 1975 ：野菜の光合成及び蒸散に関 
する研究 2. 差動トランス利用による生長記録装置及 びてれを用いてのトマト, キュウリなどの伸長肥大の 測定. 野菜試報告, A2, 33-47.

Lake, J. V., 1966: Measurement and control of the rate of carbon dioxide assimilation by glasshouse crops. Nature, 209, 97-98.

Matsui, T. and Eguchi, H., 1976: Computer control of plant growth by image processing. Environ. Control in Biol., 14, 1-7.

Methy, M. and Salager, J. L., 1989: A microcomputer-based fast data acquisition system for in-vitro measurements of stress effects in crop plants by chlorophyll fluorescence induction. Computers and Electronics in Agr., 4, 121-128.

Minagawa, H., 1994: Surface area, volume, and projected area of japanese-shorthorn cattle measured by stereo photogrammetry using nonmetric camera. J. Agric. Meteorol, 50 (1), 1722.

三輪敬之・櫛橋康博・町田浩章, 1987 ：カポックの葉表 面における生体電位変化について. 生物環境調節, 25, 123-128.

中西美一・内田 徹, 1989 : 実用型栽培支援システムの 開発. 生物環境調節, 27 (4), 145-147.

中島秀明, 1991：環境応答 (新免輝男編集), 5. 内生りズ 厶. 朝倉書店, 177-190.

中島武彦, 1993 : レタスの初期成育に及ぼす間欠補光の 影響. 園芸学会雑誌, 61 (4), 813-820.
二ノ方兼武・宮里 満, 1959 : 歪計による樹幹直径の測 定. 鹿児島大学農学部報告, 76-88.

佐々木恵彦, 1984 : 光と植物生育 (稲田勝美編著), 光と 成長運動. 養賢堂, 東京, $51-56$.

Satter, R. L., Guggino, S. E., Lonergan, T. A. and Galston, W., 1981: The effect of blue and far red light on rhythmic leaflet movements in Samanea saman and Albizzia julibrissin. Plant Physiol., 67 (5), 965-968.

関山哲雄・羽生広道・岡部勝美, 1982 ：環境ストレスに 対する植物生体反応の連続測定法の開発. 電力中央研 究所報告, $481016,33 \mathrm{pp}$.

柴岡孝雄, 1981 : 動く植物. 東京大学出版会, 東京, pp. 154.

柴田孝信・岩尾憲三・高野泰吉, 1993 ：画像処理による 自動成長計測装置の開発. 生物環境調節, 31 (1)，29 -35 .

Takakura, T., Kozai, T., Tachibana, K. and Jordan, J. A., 1974: Direct digital control of plant growth I. Design and operation of the system. Trans. of the ASAE, 17, 1150-1154.

鳥居 徹-長野敏英・石田朋靖・船田 周, 1990 : 葉色 によるメロンの成熟度判定 (2)，葉の表面色之果肉糖 濃度変化について. 生物環境調節, 28 (3), 129-131. 内田 徹・中西美一・浦田真紀, 1990：栽培環境制御の ための植物生体電位計測に関する研究 (第 1 報) ホウレ ンソウの葉面電位計測. 生物環境調節, 28 (3), 113 -118 . 